\title{
Pulmonary microvascular dysfunction and pathological changes induced by blast injury in a rabbit model
}

\author{
Si-Yu Wu, M.D.,,"1 Geng-Fen Han, M.D., ${ }^{*, 1}$ Jian-Yi Kang, M.D.,, Liang-Chao Zhang, M.D., ${ }^{2}$ \\ Ai-Min Wang, M.D., Ph.D., ${ }^{1}$ Jian-Min Wang, M.D., Ph.D. ${ }^{2,3}$
}

${ }^{1}$ Department of Orthopedics, Daping Hospital, Third Military Medical University, Chongqing, 400042, PR China

${ }^{2}$ The $6^{\text {th }}$ Department of Research Institute of Field Surgery and Daping Hospital, Third Military Medical University, Chongqing, 400042, PR China

${ }^{3}$ State Key Laboratory of Trauma, Burn and Combined Injury, Third Military Medical University, Chongqing, 400042, PR China

\begin{abstract}
BACKGROUND: Vascular leakage has been proven to play a critical role in the incidence and development of explosive pulmonary barotrauma. Quantitatively investigated in the present study was the severity of vascular leakage in a gradient blast injury series, as well as ultrastructural evidence relating to pulmonary vascular leakage.

METHODS: One hundred adult male New Zealand white rabbits were randomly divided into 5 groups according to distance from the detonator $(10 \mathrm{~cm}, 15 \mathrm{~cm}, 20 \mathrm{~cm}, 30 \mathrm{~cm}$, and sham control). Value of pulmonary vascular leakage was monitored by a radioactive I $25 \mathrm{I}$-albumin labeling method. Pathological changes caused by the blast wave were examined under light and electron microscopes.

RESULTS: Transcapillary escape rate of ${ }^{125} \mathrm{I}$-albumin and residual radioactivity in both lungs increased significantly at the distances of $10 \mathrm{~cm}, 15 \mathrm{~cm}$, and $20 \mathrm{~cm}$, suggesting increased severity of vascular leakage in these groups. Ultrastructural observation showed swelling of pulmonary capillary endothelial cells and widened gap between endothelial cells in the $10-\mathrm{cm}$ and $15-\mathrm{cm}$ groups.
\end{abstract}

CONCLUSION: Primary blast wave can result in pulmonary capillary blood leakage. Blast wave can cause swelling of pulmonary capillary endothelial cells and widened gap between endothelial cells, which may be responsible for pulmonary vascular leakage.

Keywords: Blast injury; permeability; pulmonary dysfunction; vascular leakage.

\section{INTRODUCTION}

Blast injuries are a series of minor, major, or lethal traumas that may lead to dysfunctions in pulmonary, gastrointestinal, and auditory systems. ${ }^{[1-5]}$ In the past, the majority of blast injuries were sustained during military conflict, or industrial or mining accidents. However, explosions in different kinds of

*These authors contributed equally to this work.

Address for correspondence: Ai Min Wang, M.D and jian Min Wang, M.D. Ai Min Wang: Department of Orthopedics, Daping Hospital, The Third Military Medical University, Chongqing, 400042, China. Tel: +86-023-68757936E-mail: trauma3@I63.com Jian Min Wang: $6^{\text {th }}$ Department of Research Institute of Field Surgery and State Key Laboratory of Trauma and Burn and Combined Injury, Daping Hospital, Third Military Medical University, Chongqing 400042, China. E-mail: jmwangcq@gmail.com

Qucik Response Code

Ulus Travma Acil Cerrahi Derg 2016;22(5):405-4II doi: $10.5505 /$ tjtes.2015.06005

Copyright 2016 TJTES terrorist attacks have become the leading cause of blast injuries. It has been reported that blast injuries sustained during terrorist attacks increased 4-fold from 1999 to 2006, worldwide. ${ }^{[6]}$ Therefore, investigations into the mechanism of blast injury are imperative, as they may aid in exploring solutions for blast injury patients.

Pulmonary barotrauma is one of the most critical injuries in civilian or military blast settings. It has been shown that pathological characteristics of explosive pulmonary barotrauma include alveolar hemorrhage, interstitial edema, and alveolar septa rupture. Such pathological changes are always lethal, due to impairment of gas exchange capacity. ${ }^{[2-4,6]}$ Thus far, several contributing factors for pulmonary blast injury have been identified, including direct tissue damage, progressive vascular leakage, and inflammatory changes. In particular, vascular leakage has been shown to play a critical role in the incidence and development of explosive pulmonary barotraumas. ${ }^{[7-12]}$ Although the existence and significance of vascular leakage in pulmonary blast injury has been confirmed, there has been insufficient quantitative investigation into pulmonary vascular leakage. In addition, ultrastructural evidence of pulmonary vascular leakage has not been identified. Therefore, the pri- 
mary aim of the present study was to quantitatively investigate the severity of vascular leakage in a gradient blast wave series. The secondary aim was to explore ultrastructural evidence of pulmonary vascular leakage.

\section{MATERIALS AND METHODS}

\section{Animal Model of Blast Injury}

One hundred adult male New Zealand White rabbits weighing from 2.0 to $2.5 \mathrm{~kg}$ were provided by the Experimental Animal Center of the Third Medical University. All experimental protocols were approved by the Institutional Animal Care and Research Advisory Committee, and were performed in accordance with the National Institutes of Health Guidelines for Animal Use and Care. The animals were randomly divided into 5 groups $(n=20)$, including I group that served as sham control. Each animal was anesthetized by intravenous injection of $3.0 \%$ pentobarbital-sodium at a dose of $30 \mathrm{mg} / \mathrm{kg}$, and received an intravenous injection of $2 \mathrm{mg} /$ $\mathrm{kg}$ carprofen to prevent pain. A $10-\mathrm{cm} \times 10-\mathrm{cm}$ region of the surface of the xiphoid process was shaved, and the rabbit was fixed on a specially designed plate, lying on the right side to prevent movement in response to blast impact. Electrocardiogram (ECG) was recorded with a CardiMax FX-7202 electrocardiograph (Fukuda Denshi Co. Ltd., Tokyo, Japan), with a vertical calibration of $10 \mathrm{~mm} / \mathrm{mV}$, and a horizontal paper speed of $25 \mathrm{~mm} / \mathrm{second}$. Printouts were made prior to detonation and every 10 min after detonation, or as necessary. The blast wave was generated by detonator containing $0.9 \mathrm{~g}$ trimethylene trinitramine (RDX) and $0.4 \mathrm{~g}$ diazodinitrophenol (DDNP; No. 845 Factory, Chongqing, China). The detonator was placed at the same horizontal level as the thoracoabdominal midline of the animal, pointed at the surface of the xiphoid process. In order to achieve the gradient blast injury, the detonator was set at $10 \mathrm{~cm}, 15 \mathrm{~cm}, 20 \mathrm{~cm}$ and $30 \mathrm{~cm}$ from the animals. In each group, 5 rabbits were distributed for histological observation, while the others were subjected to permeability measurement. The animals of the control group underwent the same protocols, with the exception of detonation. Certain necessary emergency treatments were conducted following detonation, such as chest compressions and methods to ensure that the respiratory tract was unobstructed.

\section{Determination of Blast Wave}

Following anesthetization by pentobarbital-sodium, each animal was placed on a specially designed wooden desk, with left forelimb secured tightly to expose the chest and abdomen. The detonator was placed vertically at the series of distances $(10 \mathrm{~cm}, 15 \mathrm{~cm}, 20 \mathrm{~cm}$ and $30 \mathrm{~cm})$, in alignment with the xiphoid process. A SK-902 piezoelectricity pressure sensor (Jili Electron Machine Factory, Yangzhou, China) was attached to the right chest. The sensor was connected to a SK6882 charge amplifier (Jili Electron Machine Factory, Yangzhou, China). Real-time signal was recorded and processed by a HP5450IA data-recording oscillograph (Hewlett-Packard Inc., Palo Alto, CA, USA) during detonation. Characteristic parameters of blast wave included peak pressure, duration of positive pressure, and the time of pressure-to-peak.

\section{Pulmonary Microvascular Permeability}

Severity of vascular leakage in a series of blast injuries was monitored by a radioactive ${ }^{125} \mathrm{I}$-albumin labeling method. After induction of anesthesia, blood samples $(3 \mathrm{ml})$ of each animal were drawn into vacutainer tubes containing ethylene diamine tetraacetic acid (EDTA) through the right jugular vein of the rabbits. Each blood sample was centrifuged at 10,000 r/min for $10 \mathrm{~min}$, hematocrit (HCT) value was determined using a ZJ2000 blood cell analyzer (Shounuote Scientific Instrument, Inc., Jiangxi, China), and ${ }^{125} \mathrm{I}$-albumin $(20 \mu \mathrm{Ci} / \mathrm{kg})$ was administered through the internal jugular vein. After 5 minutes, I $\mathrm{ml}$ of blood from animals in each group $(n=15)$ was obtained to measure radioactivity (counts/minute, $\mathrm{min}^{-1}$ ). Thirty minutes after detonation, the process was repeated. While blood was released from the femoral artery, $500 \mathrm{ml}$ $0.9 \%$ sodium solution was injected into the internal jugular vein. Thereafter, each rabbit was sacrificed to acquire value of radioactivity in both lungs. On the assumption that total red cell volume would be constant throughout the experiment, the transcapillary escape rate of total $125 \mid$-albumin $\left(R_{l}\right)$ and the rate of residual-radioactivity $\left(R_{2}\right)$ in both lungs were acquired using the following equations:

$$
\begin{aligned}
& R_{1}=\left(I-\left(H c t_{1} \times r_{2}\right) /\left(H c t_{2} \times r_{1}\right)-r_{4} / r_{t}\right) \times 100 \% \\
& R_{2}=r_{3} /\left(W_{t} \times r_{2}\right) \times 100 \%
\end{aligned}
$$

The symbol $r_{t}$ stands for total radioactivity before injury, $r_{\text {, }}$ for radioactivity per $\mathrm{ml}$ blood before injury, $r_{2}$ for radioactivity per $\mathrm{ml}$ blood after injury, $r_{3}$ for residual radioactivity of lung tissue after injury, $r_{4}$ for radioactivity of blood drawn from the femoral artery, $W_{t}$ for the weight of tissue, HCT, for HCT before injury, and $\mathrm{HCT}_{2}$ for HCT after injury.

\section{Histological Study}

Following 30 minutes of observation, the animals were sacrificed via overdose of pentobarbital until ECG became isoelectric. Lung tissue specimens of 25 rabbits $(n=5$ in each group, 5 groups) were immediately fixed in $2.5 \%$ glutaraldehyde. The specimens were dehydrated in an ascending grade of ethanol, cleared in xylene, and embedded in paraffin wax. Serial sections of 5-mm thickness were obtained using rotatory microtome. Deparaffinized sections were routinely stained with haematoxylin and eosin (HE). Photomicrographs of each slide were obtained using digital research photographic microscope (IX50; Olympus Co., Ltd., Tokyo, Japan).

\section{Ultrastructural Observation}

Ultrastructural alterations were investigated with electron microscopy. Harvested lung samples were post-fixed by $1 \%$ 
osmium tetroxide in 0.I-M sodium cacodylate buffer $(\mathrm{pH} 7.3)$ for I hour at room temperature. They were then dehydrated in ethanol and embedded in resin. Ultra-thin sections of lung samples were prepared and stained with uranyl acetate and lead citrate. They were then examined under a transmission electron microscope (TECNAI 10; Philips Healthcare, Inc., Eindhoven, Netherlands). Morphometric evaluation was conducted by an examiner who had not been informed of the experiment's design.

\section{Statistical Analysis}

Values are expressed as mean $\pm S D$. Following test for normalcy of distribution, data were analyzed with one-way analysis of variance (ANOVA) using the SPSS software package (version 13.0; SPSS Inc., Chicago, IL, USA). When significant overall difference among groups was determined, Tukey's post hoc test was used to perform pairwise comparison, and $\mathrm{p}<0.05$ was considered statistically significant.

\section{RESULTS}

\section{Distance Decay of Blast Wave in Air}

The distance decay of the blast wave was recorded by pressure sensor. Data regarding distances from the detonator are displayed in Table I. Pressure peak of blast wave and time required for pressure rise both decreased as the distance to the detonator increased, while the duration of positive pressure increased.

\section{Blast Wave Increased Pulmonary Microvascular Permeability}

Transcapillary escape rate of ${ }^{125} \mathrm{I}$-albumin was measured to evaluate the severity of vascular leakage by calculating the variation of total radioactivity in blood. It was shown that the transcapillary escape rate of ${ }^{125} \mid$-albumin significantly increased after injury at the distances of $10 \mathrm{~cm}, 15 \mathrm{~cm}$, and $20 \mathrm{~cm}$, suggesting an increase of vascular leakage in these groups $(p<0.05$, Table 2). Little influence on the transcapillary escape rate of $125 \mathrm{I}$-albumin was found in rabbits at the distance of $30 \mathrm{~cm}$ ( $p>0.05$, Table 2). In particular, the transcapillary escape rate of ${ }^{125} \mathrm{I}$-albumin at the distance of $10 \mathrm{~cm}$ was significantly higher than rates at the distances of $15 \mathrm{~cm}, 20 \mathrm{~cm}$, and $30 \mathrm{~cm}$. This outcome demonstrated that higher intensity of blast wave can result in more severe vascular leakage $(p<0.05$, Table 2$)$.

Residual radioactivity in both lungs was measured to reflect the amount of 1251-albumin leaking into the interstitial space through the damaged microvessel in the lung. The data showed that residual radioactivity significantly increased following injury at the distances of $10 \mathrm{~cm}, 15 \mathrm{~cm}$, and $20 \mathrm{~cm}$, suggesting an increased amount of vascular leakage in these groups $(p<0.05$, Table 2$)$.

\section{Animal Experiment and Pathology Results}

All animals survived the 30-minute observation period. Body surface of injured animals suffered burn and subcutaneous hemorrhage without penetrability trauma, while foliated hemorrhage was observed in the lungs. Representative photographs of HE-stained sections are shown in Fig. I. Observed in the $10-\mathrm{cm}$ group were alveolar and interstitial hemorrhage, pulmonary interstitial edema, multifocal alveolar septum fracture, focal bullae formation, and necrosis or loss of pulmonary capillary endothelial cell in lumen (Fig. Ib, c). In the 15-cm group, red blood cells were found in the alveolar lumen, and the edema of the alveolar epithelial cell

Table I. Blast wave pressure at various distances from the detonator in air (Mean \pm SD)

\begin{tabular}{lcccc}
\hline Distance $(\mathbf{c m})$ & $\mathbf{n}$ & Peak pressure $(\mathbf{k P a})$ & Duration of positive pressure $(\boldsymbol{\mu s})$ & Pressure rise time $(\boldsymbol{\mu s})$ \\
\hline 10 & 15 & $1108.30 \pm 173.75$ & $121 \pm 14$ & $24.0 \pm 7.5$ \\
15 & 15 & $381.50 \pm 46.64$ & $152 \pm 61$ & $22.0 \pm 4.7$ \\
20 & 15 & $175.43 \pm 22.34$ & $170 \pm 24$ & $18.0 \pm 4.3$ \\
30 & 15 & $68.50 \pm 13.57$ & $209 \pm 53$ & $12.0 \pm 3.6$ \\
\hline
\end{tabular}

Table 2. Change of rate of escaped and retained $125 \mathrm{I}$-albumin radiation in lung tissue after trauma caused by explosive blast at various distances from explosive center (Mean $\pm S D, n=15)$

\begin{tabular}{lcrr}
\hline Group & Rate of ${ }^{125}$ I-albumin escaped (\%) & \multicolumn{2}{c}{ Remained radiation (counts/min/g) } \\
\cline { 3 - 4 } & & Left lung & Right lung \\
\hline Control & $26.43 \pm 7.49$ & $4080.58 \pm 971.64$ & $4628.11 \pm 409.82$ \\
$10 \mathrm{~cm}$ & $41.79 \pm 6.69^{* *}$ & $7496.94 \pm 729.48^{* *}$ & $6189.36 \pm 583.80^{* * *}$ \\
$15 \mathrm{~cm}$ & $39.58 \pm 8.40^{* *}$ & $5579.31 \pm 719.32^{* *}$ & $6173.80 \pm 744.8 I^{* *}$ \\
\hline
\end{tabular}



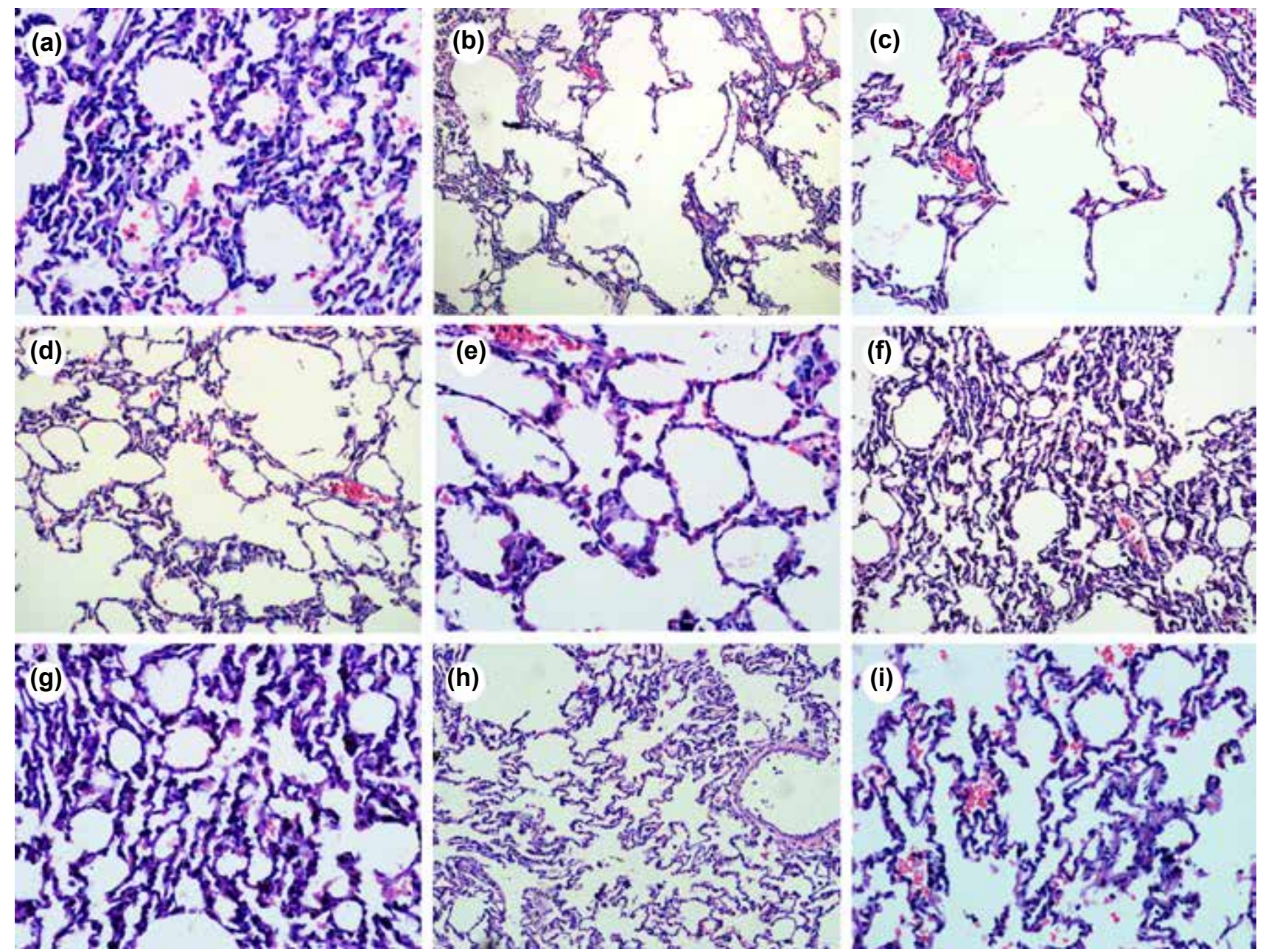

Figure 1. Representative HE micrographs of impaired lungs in normal group (a) and in blast injury groups at $10 \mathrm{~cm}(\mathbf{b}, \mathbf{c}), 15 \mathrm{~cm}(\mathbf{d}, \mathbf{e}), 20$ $\mathrm{cm}(\mathbf{f}, \mathbf{g})$, and $30 \mathrm{~cm}(\mathbf{h}, \mathbf{i})$. Original magnifications: 100×(a, b, d, f, h); 200×(c, e, g, i).

and alveolar-interstitial. Focal fracture of the alveolar septum, interstitial capillary congestion, and lymphocyte infiltration were also noted (Fig. Id, e). In the 20-cm group, red blood cells were found in the alveolar lumen, and alveolar epithelial cell edema and spotty necrosis were also noted (Fig. If, g). In the $30-\mathrm{cm}$ group, only scattered red blood cells were found in the alveolar lumen (Fig. If, h).

\section{Ultrastructural Evidence of Impaired Pulmonary Permeability}

Following blast injury, ultrastructural changes were found with transmission electron microscopy. In the 10-cm group, it was observed that pulmonary microvascular endothelial cells were generally swollen (Fig. 2b). Necrosis was also found in some endothelial cells (Fig. $2 \mathrm{c}$ ). In the $15-\mathrm{cm}$ group, the gap between pulmonary microvascular endothelial cells was significantly widened (Fig. 2d). Red blood cells had escaped through the alveolar wall, and pulmonary capillary endothelial cell swelling was noted (Fig. 2e). Neutrophils were incarcerated in the endovascular system (Fig. 2f). In the $20-\mathrm{cm}$ group, pulmonary capillary endothelial cell swelling was noted (Fig.
$2 \mathrm{~g}, \mathrm{~h})$. In the $30-\mathrm{cm}$ group, no obvious ultrastructural change was observed (Fig. 2i).

\section{DISCUSSION}

Quantitatively investigated in the present study was the severity of vascular leakage in a series of gradient blast injuries. In addition, ultrastructural evidence relating to pulmonary vascular leakage was explored. It was found that blood condensed following blast injury. The amount of vascular leakage decreased as the distance to the explosion center increased. In addition, the pulmonary capillary endothelial cells swelled, died, or were lost, and the gap between pulmonary microvascular endothelial cells widened. These phenomena may be responsible, at least in part, for the increased amount of pulmonary vascular leakage after blast injury.

Blast wave was generated by detonator containing RDX and DDNP, which are widely used in the improvised explosive devises of terrorist attacks. ${ }^{[1,6,12]}$ The detonators were placed at a series of distances $(10 \mathrm{~cm}, 15 \mathrm{~cm}, 20 \mathrm{~cm}$, and $30 \mathrm{~cm})$ to generate waves of varying intensity. It was found that peak pres- 

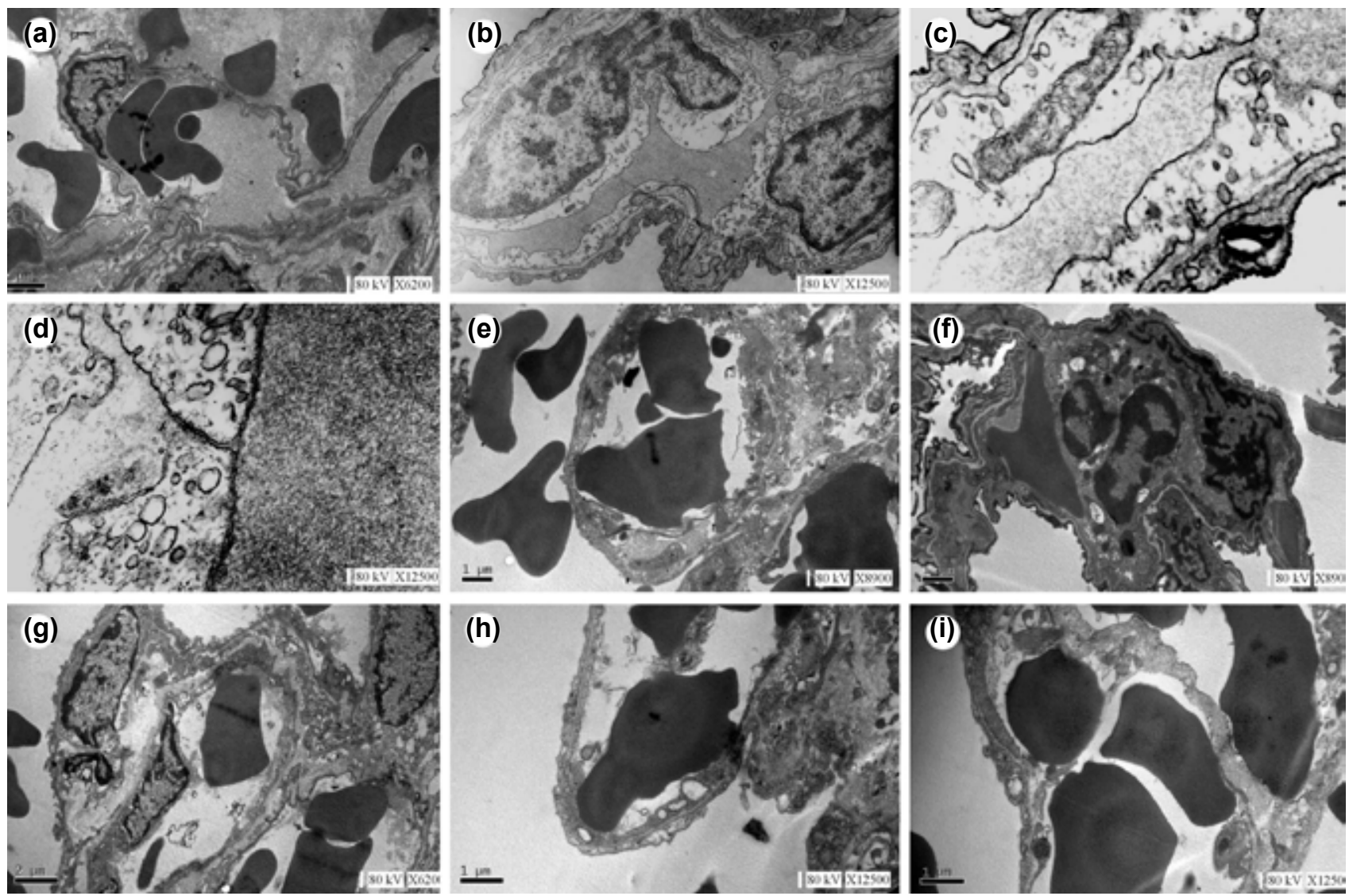

Figure 2. Representative ultrastructural appearances of impaired lungs in normal group (a) and in blast injury groups at $10 \mathrm{~cm}$ (b, c), $15 \mathrm{~cm}$ (d-f), $20 \mathrm{~cm}(\mathbf{g}, \mathbf{h})$, and $30 \mathrm{~cm}$ (i). a: normal lung; b: swelling of pulmonary microvascular endothelial cells with nuclear swelling; c: necrosis of pulmonary microvascular endothelial cells; d: significantly widened gaps between pulmonary microvascular endothelial cells; e: red blood cells escaped through the alveolar wall; f: swelling observed in the pulmonary capillary endothelial cells and neutrophils incarcerated in the endovascular system; $\mathrm{g}$ and $\mathrm{h}$ : pulmonary capillary endothelial cell swelling; i: no cell swelling was observed.

sure decreased as distance increased, while duration of positive pressure and time required for pressure rise remained relatively constant. This observation was in accordance with findings of previous studies ${ }^{[2,11,13,14]}$ and matched the characteristics of blast wave transmission in air.

Blast wave caused plasma loss in the pulmonary endothelium, which was monitored by the radioactive I25I-albumin labeling method. It was found that a blast wave of higher intensity resulted in greater pulmonary vascular leakage. Such a finding was evidenced by higher rates of $125 \mid$-albumin escape and greater residual radioactivity in the lungs of rabbits in the $10-\mathrm{cm}$ and $15-\mathrm{cm}$ groups. The extent of pulmonary vascular leakage was highly correlated with damage to pulmonary endothelial cells. Under a relatively low pressure (such as that of the $20-\mathrm{cm}$ group), pulmonary capillary endothelial cells were somewhat swollen, but the gap between endothelial cells was not affected. However, under higher pressures (such as those of the $10-\mathrm{cm}$ and $15-\mathrm{cm}$ groups), the gap between pulmonary capillary endothelial cells widened, and more severe damage was observed. It was clear that blast waves had destroyed pulmonary capillary endothelial cells, and that cells had widened, resulting in vascular leakage.
The pulmonary endothelium participates in the exchange of water and solute between the blood and the interstitium. In normal conditions, a small amount of fluid is filtered across the endothelial monolayer and drained by the lymphatic system. Fluid filtration is limited by endothelium continuity, with multiple connections between the cells called tight and adherens junctions. ${ }^{[15,16]}$ Thus, water and solute flux is strictly regulated, occurring passively between endothelial cells, termed the paracellular pathway, and driven by the hydrostatic pressure gradient between intravascular and perivascular space. ${ }^{[16-18]}$ Albumin and other macromolecules are actively transported through endothelial cells by an elaborate vesicle system known as the transcellular pathway. ${ }^{[16,19-21]}$ In the present study, swollen pulmonary capillary endothelium and widened gap between endothelial cells were observed following injury. Water and solute may easily leak out of the capillary vessel through the widened gap, a reverse result of blood condensation. Therefore, the widened gap and swollen endothelial cells that resulted from the blast wave may be the ultrastructural basis for the increased severity of vascular leakage and blood condensation. Vascular leakage was a significant cause of pulmonary edema. 
It was found that the gap between the pulmonary microvascular endothelial cells widened significantly, and that red blood cells had escaped through the alveolar wall, a significant cause of pulmonary hemorrhage. Blast overpressure simultaneously exerts compressive forces on the extravascular fluid, driving it into the alveolar space and causing pulmonary edema and alveolar hemorrhage. ${ }^{[22]}$ It has been demonstrated in animal studies that edema and hemorrhage increase lung weight and correlate with blast peak pressure and mortality. ${ }^{[23]}$ Therefore, it is very necessary to manage pulmonary edema and hemorrhage. It has also been demonstrated that administration of hemostatic nanoparticles led to significant improvement in short-term survival, and that no complications were observed. ${ }^{[24]}$

Blast injury often leads to severe systemic inflammatory response and multiple organ dysfunction. Acute lung injury (ALI) and its most severe extreme, acute respiratory distress syndrome (ARDS) refer to increased permeability in pulmonary edema caused by a variety of pulmonary or systemic insults. ${ }^{[25]}$ TNF- $\alpha$ and IL- 6 are involved in the pathogenesis and development of ARDS in blast injury. ${ }^{[26]}$ Haemoxygenase-I activated by hemin was reported to increase survival in rats with blast lung, possibly involving an anti-inflammatory mechanism, ${ }^{[27]}$ while administration of antioxidant $\mathrm{N}$-acetylcysteine amide was shown to facilitate lung recovery from inflammatory damage, protection that could be vital in situations of more severe blunt lung trauma with progression to ALI/ ARDS. ${ }^{[28]}$ In a clinical scenario, studies have shown improved outcome of severe sepsis/systemic inflammatory response with the use of activated protein $C$, steroid replacement, and aggressive control of blood glucose following blast injury. ${ }^{[2]}$

ALI and ARDS are usually accompanied by hypoxemia and the need for mechanical ventilation. The risk of air embolism from positive pressure ventilation has led to a variety of methods of ventilation, such as limited peak inspiratory pressure with permissive hypercapnia, intermittent mechanical ventilation, and high-frequency ventilation, to varying degrees of success. ${ }^{[30]}$ Pneumothorax as a result of lung rupture is the chief reason for early death and dysfunction of the circulatory system, and is also an important cause of early death. [26] Endotracheal intubation should be instituted to maintain the artificial ventilation required in cases of pulmonary blast injury. It is worth noting that positive pressure from mechanical ventilation may cause rapid increase in pneumothorax size by inducing lung tissue disruption and increasing air leakage into the pleural space. ${ }^{[3]}$

In conclusion, it was demonstrated in the present study that primary blast wave can result in blood condensation and increase in pulmonary microvascular permeability. In addition, not only can blast wave cause pulmonary capillary endothelial cell swelling, but it can also widen the gap between endothelial cells, which may cause increasing severity of pulmonary vascular leakage and blood condensation. The present find- ings provide novel histological evidence of pulmonary blast injury, which may aid in better understanding of the mechanism of this critical disease.

\section{Acknowledgement}

The present work was supported by grants from the National Natural Science Foundation of China (No: 10776038). The authors would like to thank Mr. Chen Ziqiang, Li Qinlong, M.D., and Diao Xinwei, M.D. for their excellent work in the laboratory during the histological study.

Conflict of interest: None declared.

\section{REFERENCES}

1. DePalma RG, Burris DG, Champion HR, Hodgson MJ. Blast injuries. N Engl J Med 2005;352:1335-42. Crossref

2. Elsayed NM. Toxicology of blast overpressure. Toxicology 1997;121:115. Crossref

3. Leibovici D, Gofrit ON, Stein M, Shapira SC, Noga Y, Heruti RJ, et al. Blast injuries: bus versus open-air bombings-- a comparative study of injuries in survivors of open-air versus confined-space explosions. J Trauma 1996;41:1030-5. Crossref

4. Mayorga MA. The pathology of primary blast overpressure injury. Toxicology 1997;121:17-28. Crossref

5. Wightman JM, Gladish SL. Explosions and blast injuries. Ann Emerg Med 2001;37:664-78. Crossref

6. Wolf SJ, Bebarta VS, Bonnett CJ, Pons PT, Cantrill SV. Blast injuries. Lancet 2009;374:405-15. Crossref

7. Avidan V, Hersch M, Armon Y, Spira R, Aharoni D, Reissman P, et al. Blast lung injury: clinical manifestations, treatment, and outcome. Am J Surg 2005;190:927-31. Crossref

8. Chaloner E. Blast injury in enclosed spaces. BMJ 2005;331:119-20.

9. Crabtree J. Terrorist homicide bombings: a primer for preparation.J Burn Care Res 2006;27:576-88. Crossref

10. Eckert MJ, Clagett C, Martin M, Azarow K. Bronchoscopy in the blast injury patient. Arch Surg 2006;141:806-11. Crossref

11. Elsayed NM, Gorbunov NV. Pulmonary biochemical and histological alterations after repeated low-level blast overpressure exposures. Toxicol Sci 2007;95:289-96. Crossref

12. Pizov R, Oppenheim-Eden A, Matot I, Weiss YG, Eidelman LA, Rivkind AI, et al. Blast lung injury from an explosion on a civilian bus. Chest 1999;115:165-72. Crossref

13. Bauman RA, Elsayed N, Petras JM, Widholm J. Exposure to sublethal blast overpressure reduces the food intake and exercise performance of rats. Toxicology 1997;121:65-79. Crossref

14. Rosenfeld JV, Ford NL. Bomb blast, mild traumatic brain injury and psychiatric morbidity: a review. Injury 2010;41:437-43. Crossref

15. Bazzoni G, Dejana E. Endothelial cell-to-cell junctions: molecular organization and role in vascular homeostasis. Physiol Rev 2004;84:869-901.

16. Mehta D, Malik AB. Signaling mechanisms regulating endothelial permeability. Physiol Rev 2006;86:279-367. Crossref

17. Lucas R, Verin AD, Black SM, Catravas JD. Regulators of endothelial and epithelial barrier integrity and function in acute lung injury. Biochem Pharmacol 2009;77:1763-72. Crossref

18. Vandenbroucke E, Mehta D, Minshall R, Malik AB. Regulation of endothelial junctional permeability. Ann N Y Acad Sci 2008;1123:134-45.

19. Minshall RD, Malik AB. Transport across the endothelium: regulation of endothelial permeability. Handb Exp Pharmacol 2006;(176 Pt 1):10744. 
20. Minshall RD, Sessa WC, Stan RV, Anderson RG, Malik AB. Caveolin regulation of endothelial function. Am J Physiol Lung Cell Mol Physiol 2003;285:L1179-83. Crossref

21. Predescu SA, Predescu DN, Malik AB. Molecular determinants of endothelial transcytosis and their role in endothelial permeability. Am J Physiol Lung Cell Mol Physiol 2007;293:L823-42. Crossref

22. Crabtree J. Terrorist homicide bombings: a primer for preparation.J Burn Care Res 2006;27:576-88. Crossref

23. Elsayed NM. Toxicology of blast overpressure. Toxicology 1997;121(1):1-15. Crossref

24. Lashof-Sullivan MM, Shoffstall E, Atkins KT, Keane N, Bir C, VandeVord P, et al. Intravenously administered nanoparticles increase survival following blast trauma. Proc Natl Acad Sci U S A 2014;111:10293-8.

25. Maniatis NA, Kotanidou A, Catravas JD, Orfanos SE. Endothelial pathomechanisms in acute lung injury. Vascul Pharmacol 2008;49:11933. Crossref
26. Fan CX, Zhang ZP, Cheng QS, Li YZ, Zhu YF, Wang J, et al. Experimental study on acute respiratory distress syndrome and analysis of relevant factors in rabbits subjected to thoracic blast trauma. [Article in Chinese] Zhongguo Wei Zhong Bing Ji Jiu Yi Xue 2011;23:243-6. [Abstract]

27. Chavko M, Prusaczyk WK, McCarron RM. Protection against blastinduced mortality in rats by hemin. J Trauma 2008;65:1140-5. Crossref

28. Chavko M, Adeeb S, Ahlers ST, McCarron RM. Attenuation of pulmonary inflammation after exposure to blast overpressure by $\mathrm{N}$-acetylcysteine amide. Shock 2009;32:325-31. Crossref

29. Lavery GG, Lowry KG. Management of blast injuries and shock lung. Curr Opin Anaesthesiol 2004;17:151-7. Crossref

30. Pizov R, Oppenheim-Eden A, Matot I, Weiss YG, Eidelman LA, Rivkind AI, et al. Blast lung injury from an explosion on a civilian bus. Chest 1999;115:165-72. Crossref

31. Karapolat S, Gezer S, Aydin LY, Dumlu T, Kandis H. Management of traumatic pneumothorax. Hong Kong Med J 2010;16:413.

\section{DENEYSEL ÇALIŞMA - ÖZET}

\section{Bir tavşan modelinde blast travmasıyla indüktlenen pulmoner mikrovasküler disfonksiyon ve patolojik değişiklikler}

\section{Dr. Si-Yu Wu, ${ }^{1}$ Dr. Geng-Fen Han, ${ }^{1}$ Dr. Jian-Yi Kang, ${ }^{2}$ Dr. Liang-Chao Zhang, ${ }^{2}$ Dr. Ai-Min Wang, ${ }^{1}$ Dr. Jian-Min Wang ${ }^{2,3}$}

${ }^{1}$ Üçüncü Askeri Tıp Üniversitesi, Daping Hastanesi, Ortopedi Bölümü, Chongqing, 400042, PR Çin

${ }^{2}$ Üçüncü Askeri Tıp Üniversitesi, Daping Hastanesi ve Alan Cerrahisi 6. Araştırma Enstitüsü Departmanı,, Chongqing, 400042, PR Çin

${ }^{3}$ Üçüncü Askeri Tıp Üniversitesi, Key Devlet Travma, Yanık ve Kombine Yaralanmalar Laboratuvarı, Chongqing, 400042, PR Çin

AMAÇ: Eksplosif pulmoner barotravmada vasküler kaçağın kritik bir rol oynadığı kanıtlanmıştır. Bu çalısmada vasküler kaçağın bir giderek artan şiddet derecesindeki blast travması serisinde şiddet derecesiyle pulmoner vasküler kaçağa ilişkili altyapısal kanıtlar kantitatif olarak araştırıldı.

GEREÇ VE YÖNTEM: Yüz adet erkek beyaz Yeni Zelanda tavşan detonatörden uzaklıklarına göre beş gruba randomize edildi $(10 \mathrm{~cm}, 15 \mathrm{~cm}, 20$ $\mathrm{cm}, 30 \mathrm{~cm}$ ve plasebo kontrol). Pulmoner vasküler kaçağın miktarı radyoaktif I25 I-albümin etiketleme yöntemiyle izlendi. Blast dalgasının neden olduğu patolojik değişiklikler ışı ve elektron mikroskobuyla incelendi.

BULGULAR: I25I-albüminin kapillerlerden kaçış hızı ve her iki akciğerde rezidüel radyoaktivite detonatörden I0, 15 ve $20 \mathrm{~cm}$ mesafede anlamlı derecede artmış olması bu gruplarda şiddetli derecede vasküler kaçağın olduğunu düşündürmektedir. Ultrastrüktürel gözlem 10 ve $15 \mathrm{~cm}$ 'lik gruplarda akciğer kapillerlerinde ödem ve endotel hücreleri arasındaki mesafenin açıldığını gösterdi.

TARTIŞMA: Primer blast dalgası akciğer kapillerlerinden kan sızıntısına neden olabilmektedir. Blast dalgası akciğer kapillerlerinin endotel hücrelerinin şişmesine neden olabilmekte, endotel hücrelerinin arasındaki mesafenin artması pulmoner vasküler kaçaktan sorumlu olabilmektedir.

Anahtar sözcükler: Blast travması; permeabilite; pulmoner disfonksiyon; vasküler kaçak.

Ulus Travma Acil Cerrahi Derg 2016;22(5):405-4II doi: 10.5505/tjtes.2015.06005 